\title{
TANAGRA MISSISSIPENSIS.
}

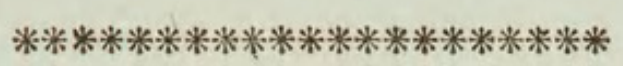

CHARACTER GENERICUS.

Rostrum conicum, acuminatum, emarginatum, basi subtrigonum, apice declive.

$$
\text { Lin. Syst. Nat. p. } 313 .
$$

CHARACTER SPECIFICUS, $\xi^{\circ} \mathrm{C}$.

TANAGRA tota rubra, rostro fusco.

TANAGRA tota rubra.

Lath. ind. orn. p. 421.

Cardinalis Mexicanus.

$$
\text { Briss. av. 3. p. } 46 .
$$

Varias Americæ partes incolit hæc avis, magnitudine Tanagram Brasiliensem æquans. 



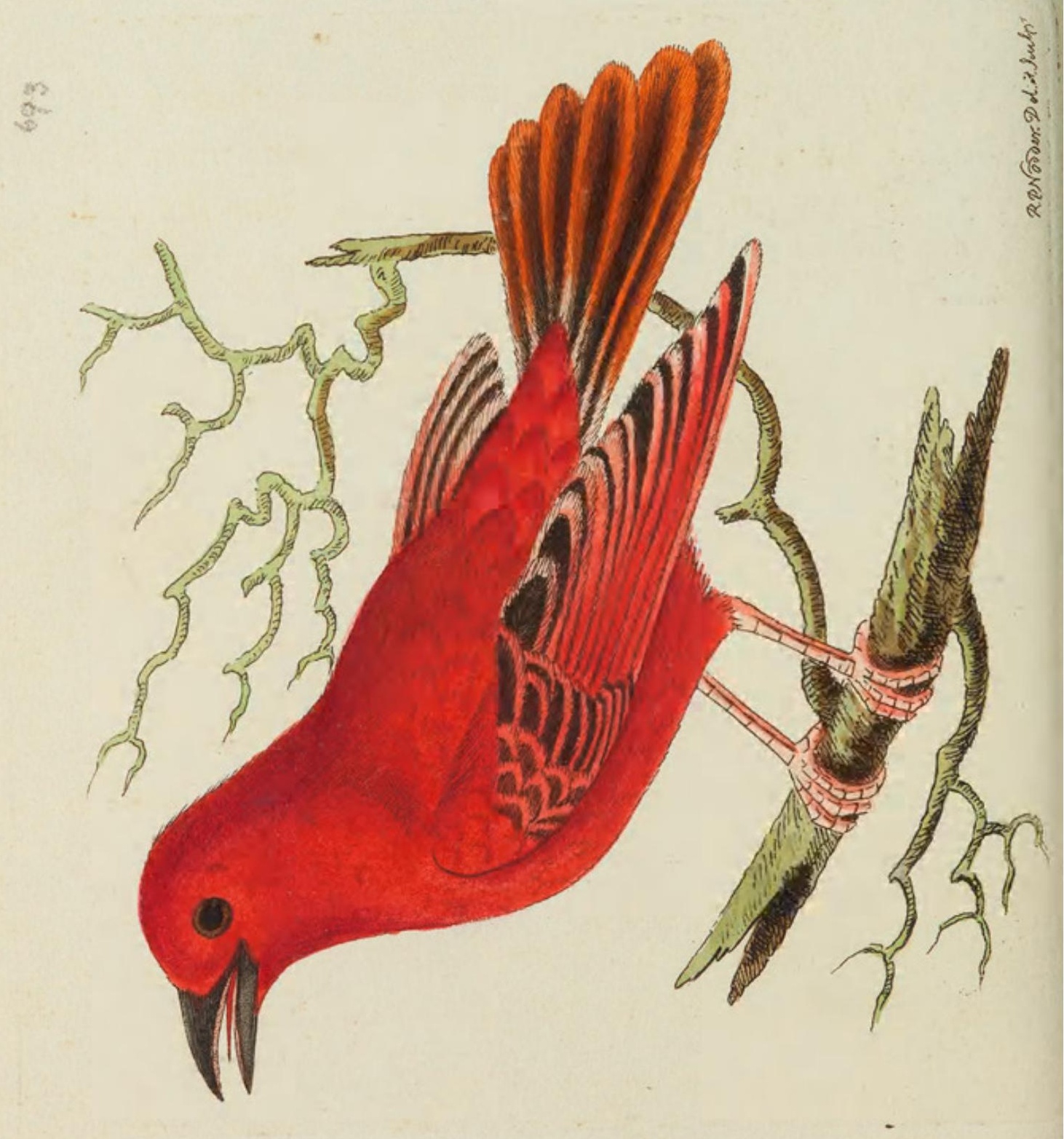




\section{MISSISSIPPI TANAGER.}

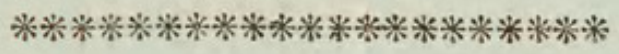

GENERIC CHARACTER.

Bill conic, acuminated, a little inclining towards the point; the upper mandible slightly ridged, and notched near the end.

SPECIFIC CHARACTER, छc.

Red TANAGER, with brown beak. MISSISSIPPI TANAGER.

Lath. Syn. 2. p. 218. TANGARA du MISSISSIPPI.

$$
\begin{aligned}
& \text { Buff. 4. p. } 252 . \\
& \text { Pl. Enl. } 741 .
\end{aligned}
$$

This species is found in several parts of America, and is equal in size to the Brasilian Tanager. 


\section{$2 \mathrm{BHL}$ Biodiversity Heritage Library}

Shaw, George. 1806. "The Mississippi Tanager, Tanagra mississippensis [PI. 693]." The Naturalist's Miscellany 17(CC), https://doi.org/10.5962/p.311131.

View This Item Online: https://www.biodiversitylibrary.org/item/281954

DOI: https://doi.org/10.5962/p.311131

Permalink: https://www.biodiversitylibrary.org/partpdf/311131

\section{Holding Institution}

Museums Victoria

\section{Sponsored by}

Atlas of Living Australia

\section{Copyright \& Reuse}

Copyright Status: Public domain. The BHL considers that this work is no longer under copyright protection.

This document was created from content at the Biodiversity Heritage Library, the world's largest open access digital library for biodiversity literature and archives. Visit BHL at https://www.biodiversitylibrary.org. 